Man and Nature

L'homme et la nature

\title{
William Blake and Westminster Abbey
}

\section{E. Reisner}

Volume 1, 1982

URI : https://id.erudit.org/iderudit/1011802ar

DOI : https://doi.org/10.7202/1011802ar

Aller au sommaire du numéro

Éditeur(s)

Canadian Society for Eighteenth-Century Studies / Société canadienne d'étude du dix-huitième siècle

ISSN

0824-3298 (imprimé)

1927-8810 (numérique)

Découvrir la revue

Citer cet article

Reisner, M. E. (1982). William Blake and Westminster Abbey. Man and Nature / L'homme et la nature, 1, 185-198. https://doi.org/10.7202/1011802ar

Copyright (C Canadian Society for Eighteenth-Century Studies / Sociéte canadienne d'étude du dix-huitième siècle, 1982
Ce document est protégé par la loi sur le droit d'auteur. L'utilisation des services d'Érudit (y compris la reproduction) est assujettie à sa politique d'utilisation que vous pouvez consulter en ligne.

https://apropos.erudit.org/fr/usagers/politique-dutilisation/ 


\section{William Blake and Westminster Abbey}

The profound impression made on Blake's mind by "those neglected works of art, called Gothic monuments" has been emphasized by all his biographers since Benjamin Heath Malkin who, in 1806, the same year that Blake began work on his Canterbury Pilgrims, ${ }^{2}$ wrote the first memoir of the artist's life. Blake's early assignment to sketch old monuments - primarily in Westminster Abbey - was a "circumstance he always mention[ed] with gratitude." ${ }^{3}$ Undoubtedly the five years he spent there making drawings laid the foundation of his life-long belief that Gothic form 'is Living Form' and exemplifies true art. ${ }^{4}$ Attribution to Blake the apprentice of drawings made from effigies in the Abbey to illustrate Richard Gough's Sepulchral Monuments in Great Britain ${ }^{5}$ and other Abbey subjects executed for the Society of Antiquaries ${ }^{6}$ have broadened our knowledge of Blake's experience in the Abbey church and his awareness of its treasures. Yet beyond allusions to gothic motifs decorating Blake's illuminated verse ${ }^{7}$ or lending symmetry to some of his designs ${ }^{8}$ there has been little interest in what he may have learned there. We are told in a general way that Blake used the sculpturesque forms in the Abbey to frame his idea of "the aspect of an angel," the calm recumbance of death" and "the pure \& spiritual character of the female expression \& form" $"$ but the monuments in Westminster Abbey have never been examined with a view to their specific impact on Blake's art and thought. ${ }^{12}$

Gilchrist pictures Blake in the Abbey as quite alone - limited in his movements only "during service and in the intervals of visits from strangers." 13 Malkin's description of him frequently standing on monuments "and viewing the figures from the top" 14 hardly suggests the supervision of anyone concerned about either damage or decorum. Blake probably saw few people; the three weekday services ${ }^{15}$ were open only to the Chapter, members of the foundation and Westminster School. ${ }^{16}$ Congregations were lamentably small. ${ }^{17}$ The choir and organ accompanying every service ${ }^{18}$ would, however, have lent atmosphere to his task and punctuated his working day. Other ceremonies were infrequent. The House of Lords attended twice a year. ${ }^{19}$ Funerals, numbering about twenty per annum in the eighteenth century, usually took place at night or were performed perfunctorily, the body never being carried into the Abbey at all. ${ }^{20}$ As to visitors, until 1826 it was impossible to enter any part of the Abbey outside the hours of service without paying a fee. ${ }^{21}$ From the beginning of Georgé III's reign, as Jocelyn Perkins 
writes, "the neglect suffered by the fabric was unbelievable . . the condition of the monuments was filthy in the extreme . . . No one troubled to emphasize its sacred character." ${ }^{22}$ Had Blake not been sent there, it is likely that his idea (especially during these formative years) of the Abbey's interior and monuments would have come from Sir Roger de Coverley's ${ }^{23}$ and Lien Chi Altangi's ${ }^{24}$ accounts of them rather than from the freedom to touch and climb on, to visit and re-visit, daily, for a period of years, some of the most beautiful relics of mediaeval craftsmanship in all England.

It was probably in the Abbey that Blake's fierce sense of the unity of art and craft took root ${ }^{25}$ for it was no doubt here that he first gained access to original works of art executed in precious materials. His previous studies had been with plaster casts and copies. ${ }^{26}$ Here were effigies carved in alabaster or cast in bronze, comatesque mosaics, ${ }^{27}$ magnificent brasses like huge engraved plates, ${ }^{28}$ the opus Alexandrinum pavement in the presbytery, "unequalled outside of Rome itself," 29 and the fourteenth-century Sedilia which, in W. Burges's view, is "quite equal, if not superior, to contemporary Italian art." 30 Although not instructed to sketch them, he must have seen John of St. Albans' thirteenth-century angel spandrels in the south transept ${ }^{31}$ and Lawrence Imber's sculptured saints, "in good preservation and . . . full of character" 32 ranged in Henry VII's Chapel, itself a magnificently exuberant Gothic structure. $^{33}$ The Chapel choir stalls were carved from motifs after Blake's favourite Albrecht Dürer and other German artists. ${ }^{34}$ The bronze effigies of its founder, Henry Tudor, his queen, Elizabeth of York, and Lady Margaret Beaufort, his mother, all justly regarded as "among the very noblest [monumental effigies] in Europe" ${ }^{35}$ were executed by Torrigiani, who worked in the same studio with another of Blake's idols, Michelangelo. ${ }^{36}$ It must have been with such works in mind that Blake later deplored the contemporary approach to beautifying public buildings, "[which] lament and desire," Laurence Binyon writes, "show how [Blake] conceived of the function and need of art in national life. Isolated in his own age, he was ever conscious of the lost medieval tradition and striving to take up again its broken threads." 37 The Abbey's beautiful originals represented the tradition that wedded art to craft, sculpture to stonemasonry, ${ }^{38}$ goldsmithing to foundry work, ${ }^{39}$ conception to execution, before the fragmentation that relegated craft to drudgery and disrepute.

In 1779, just before he was free of his indentures, Blake applied for admission to the Royal Academy of Arts. ${ }^{40}$ At this time, history painting, albeit with little pretence to historical accuracy as yet, was the dominant genre. ${ }^{41}$ Fresh from contact with mementos of the heroic past as exemplified by Abbey monuments, Blake no doubt had some basic knowledge of the dress appropriate to various periods; yet his early history paintings, as Anthony Blunt points out, employ the mixed costume favoured by Angelica Kauffmann and John Hamilton Mortimer. ${ }^{42}$ With the ' 80 s and '90s, and the artist-antiquarian approach to history painting introduced by Benjamin West and John Singleton Copley, however, research and historical accuracy began to take on new importance. ${ }^{43}$ Illustrations of authentic historical costume and armour, published by Joseph Strutt, ${ }^{44}$ Francis Grose ${ }^{45}$ and others, ${ }^{46}$ became routine sources for the history painter. In this context, it is not surprising that 


\section{PLANCHE I}

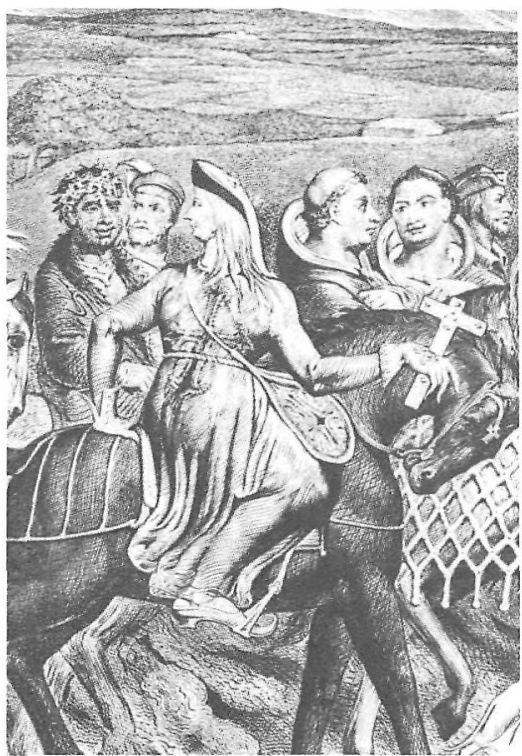

I a. The Pardoner from Blake's Canterbury Pilgrims
PLATE I

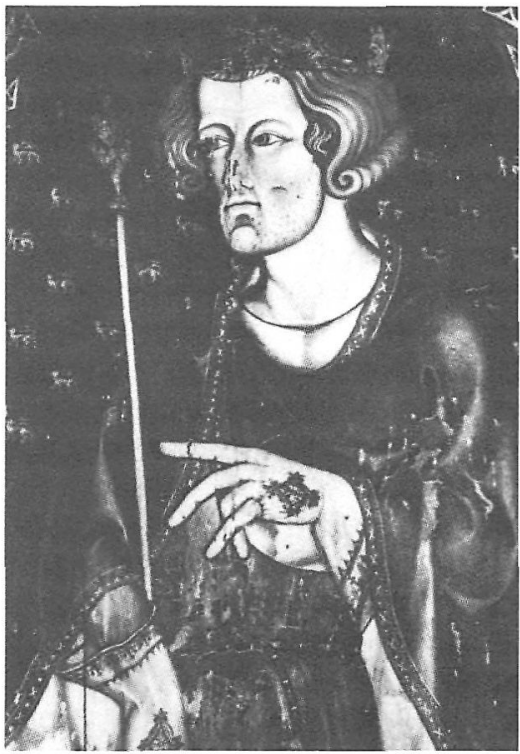

I b. The Sedilia, Westminster Abbey

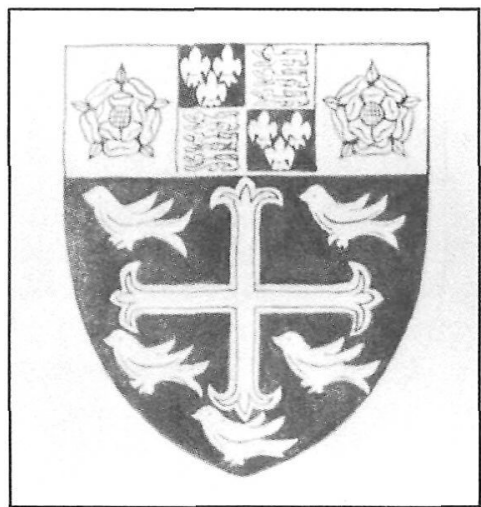

I c. Coat of arms, Westminster Abbey

I a, II a, IV a from Chaucer's Canterbury Pilgrims by William Blake, reproduced by permission of the Department of Rare Books and Special Collections, McGill University Libraries, Montreal.

I b, II b, c, d, IV b reproduced by permission of the Dean and Chapter, Westminster. 


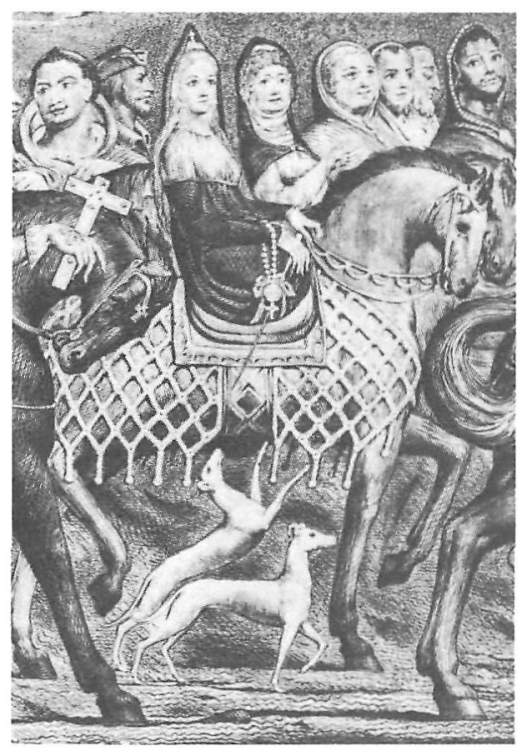

II a. The Prioress and the Nun

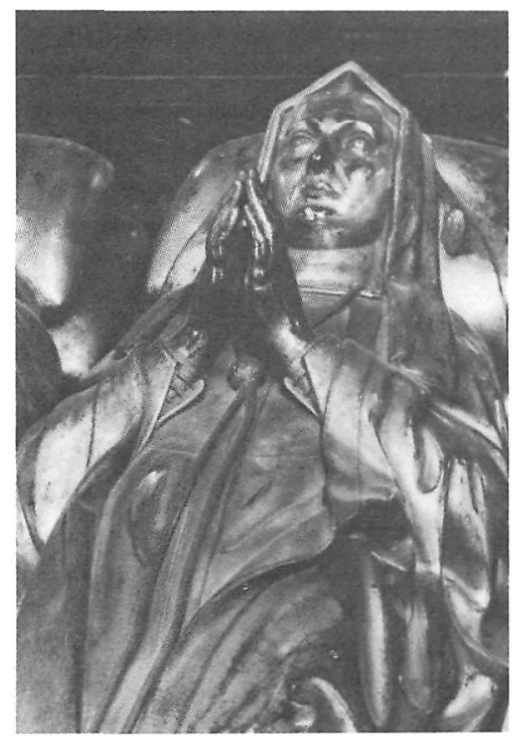

II c. Tomb effigy, Elizabeth of York, Westminster Abbey

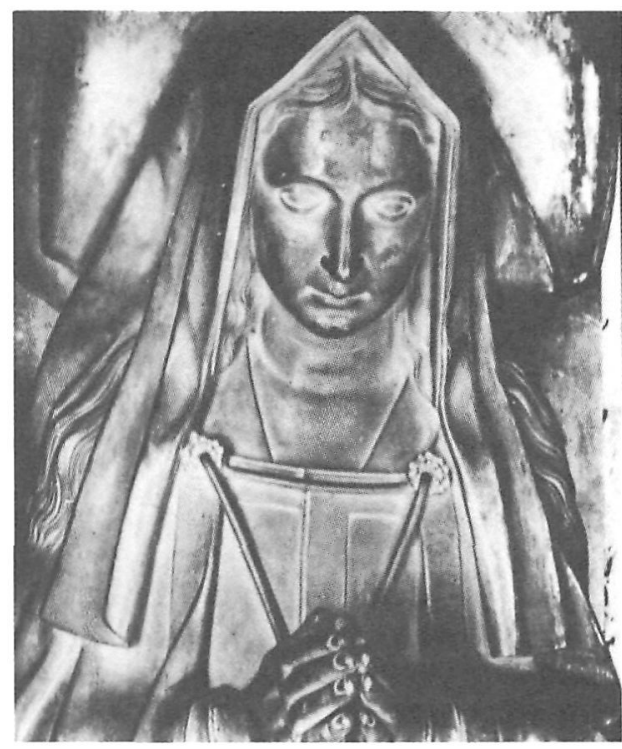

II b. Tomb effigy, Elizabeth of York, Westminster Abbey

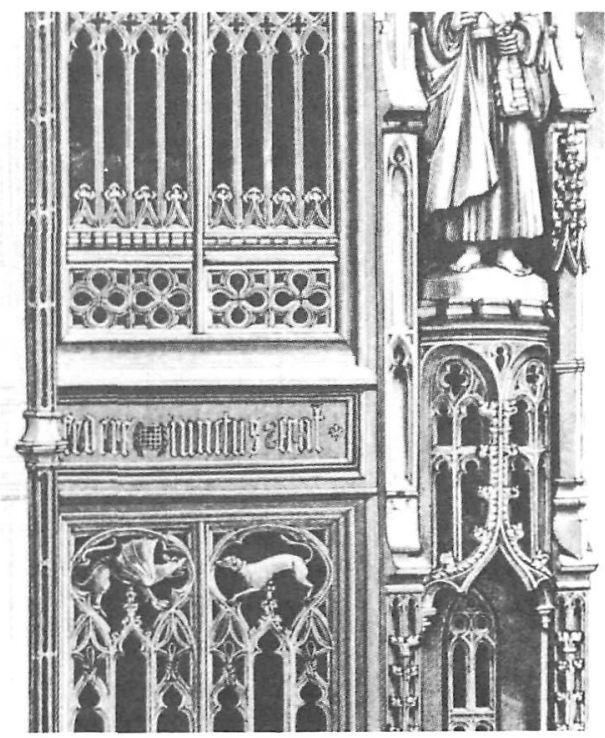

II d. Partial view of bronze grille showing greyhound and dragon badges. From Scott's Gleanings ... ( see note 28 ) 

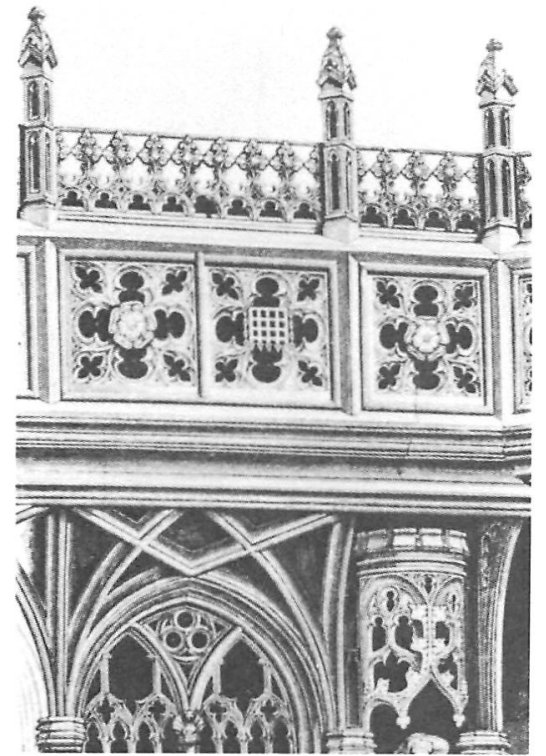

III a. Partial view of bronze grille showing rose and portcullis. From Scott's Gleanings . . .

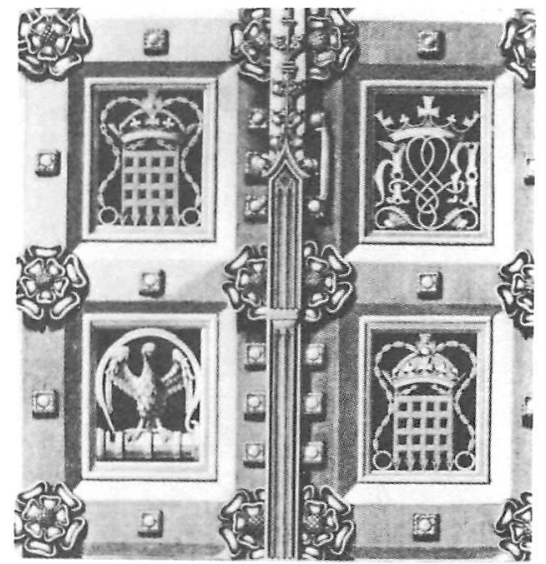

III b. Partial view of Henry VII's Chapel gate. From Scott's Gleanings...

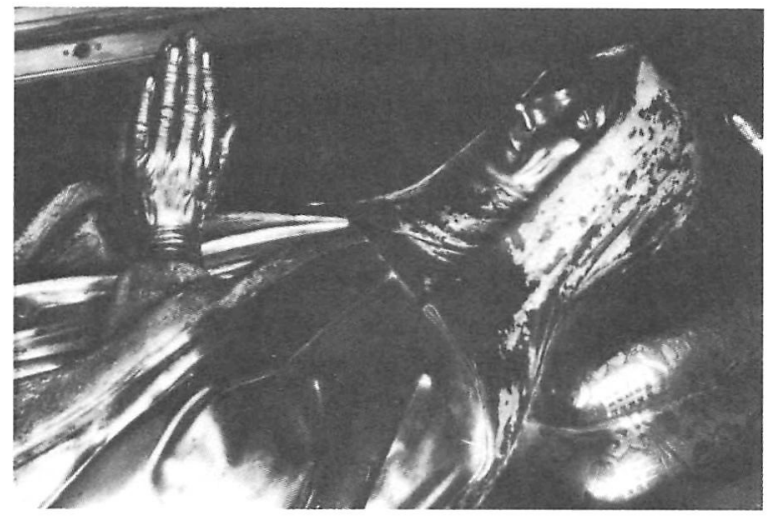

III c. Tomb effigy, Lady Margaret Beaufort, Westminster Abbey 
PLANCHE IV

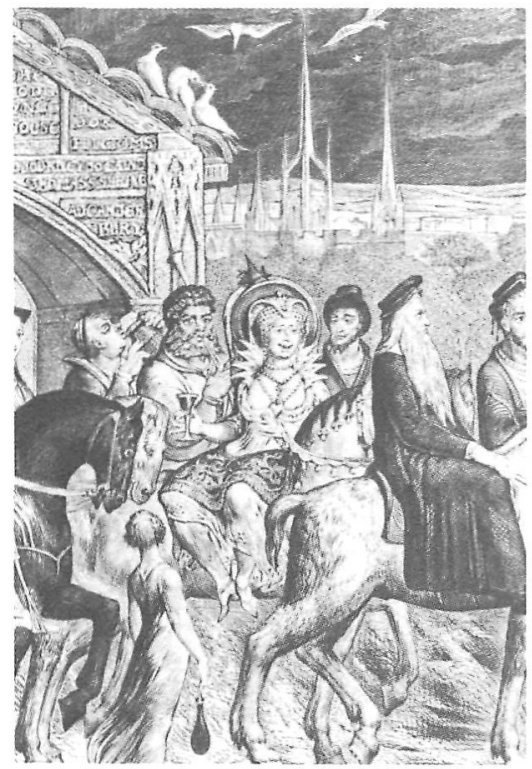

IV a. The Wife of Bath
PLATE IV

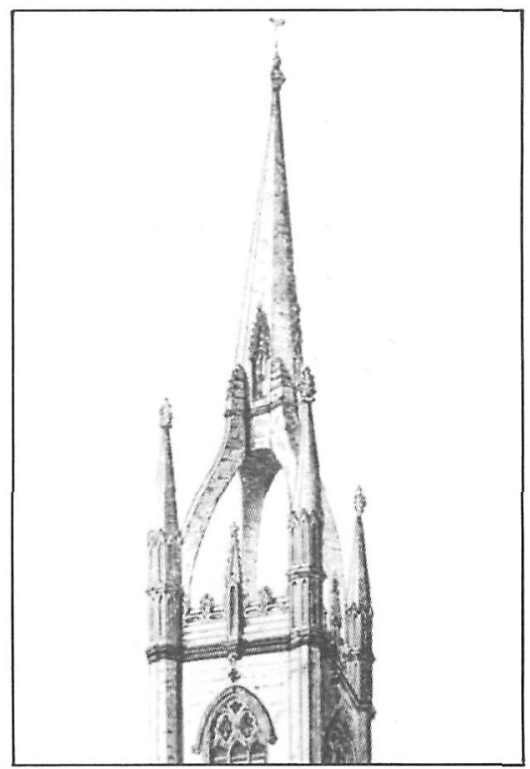

IV b. St. Dunstan's in the East. From Bohn's Pictorial Handbook ... (see note 86 )

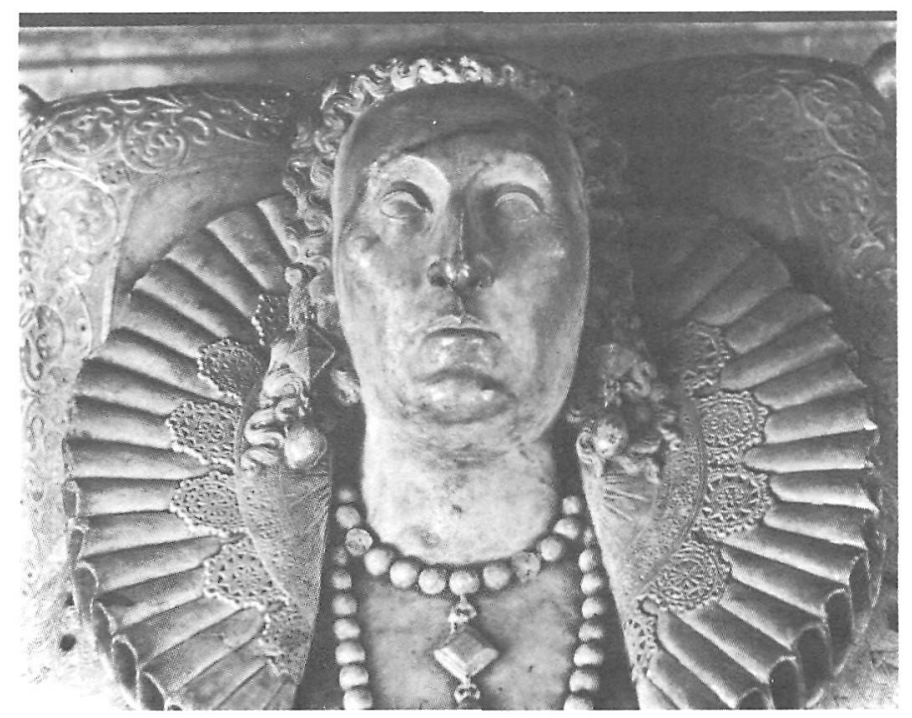

IV c. Tomb effigy, Elizabeth I,

Westminster Abbey 
Blake, in 1810 , should emphasize his fidelity to the architectural style of the Tabard Inn, in his Canterbury Pilgrims, and that he should describe the costume of his characters as "correct according to authentic monuments." ${ }^{47}$ Blake made these claims, no doubt with an eye to Thomas Stothard's Pilgrimage to Canterbury, the costumes for which were taken from Strutt's Dress and Habits of the People of England. ${ }^{48}$ What better counter-thrust at this thief of his subject, as Blake believed Stothard to be, than impugning the accuracy of his reading of Chaucer and claiming rival researches - not in antiquarian volumes but directly from authentic monuments? At first glance, one might suppose that Blake's assertions were mere bravado, for the Canterbury Pilgrims obviously employs the mixed costume of an earlier style of history painting. Yet since, as we shall see, many of his pilgrims do exhibit striking similarities in costume, and indeed in other features, to specific Abbey monuments, Blake's claim was well-founded and intended to be taken literally. Here, it would seem, is a fruitful means of gauging the Abbey's impact on a particular composition long recognized as central to Blake's philosophy of criticism, history and the nature of poetic vision.

Details of the Pardoner's costume - his gloves, for example - illustrate Blake's fidelity to monumental originals in the Abbey. They closely resemble those on Robert Waldeby's brass in St. Edmund's Chapel where Blake sketched the effigies of John of Eltham and Edward III's infant children. The fourteenth-century likeness shows him in archiepiscopal robes, the right hand raised in benediction, the left holding a cross. ${ }^{49}$ Similar jewelled gauntlets figure in Henry III's portrait on the Sedilia, faithfully rendered in Blake's copy of it, ${ }^{50}$ and are clearly suggested by the metal quatrefoils on the backs of Edward I's hands, the exhumation and unwrapping of whose corpse Blake is believed to have both witnessed and progressively recorded in sketches. ${ }^{51}$ The croix patonce on the Pardoner's back appears as part of the inscription on Henry III's tomb. ${ }^{52}$ More importantly, it forms the basis of Edward the Confessor's Cross, seen sculptured in the south aisle ${ }^{53}$ and featured most prominently in the Abbey's coat of arms. The usurpation of symbols and garments appropriate to leaders of the Church and State underscores the Pardoner's will to power. Blake describes him as "the Age's Knave, who always commands and domineers over the high and low vulgar. This man is sent in every age for a rod and scourge, . . . he is in the most holy sanctuary, and he is suffered by Providence for wise ends. . . ." ${ }^{54}$ The costume to which he has no just claim serves to emphasize his presence among the upper classes near the front of the cavalcade, where he has no right to be. ${ }^{55}$ The cross on his back recalls the Confessor's shrine in the heart of the Abbey and parodies its use on crusaders' tunics - a habit alluded to in Edmund Crouchback's name $^{56}$ whose sanctuary tomb Blake sketched. Chaucer's Pardoner, on concluding his Tale, attempts to wrest the leadership of the pilgrims from Harry Bailly. ${ }^{57}$ Blake's rendition of the Pardoner's costume reinforces this element of Chaucer's characterization.

Of all Blake's pilgrims, it is the Prioress and the Wife of Bath whose costumes and characters have received the greatest critical attention. That he intended them to be regarded as complements of each other seems clear from Blake's comment, that "the characters of Women Chaucer has divided into 
two classes, the Lady Prioress and the Wife of Bath. Are not these leaders of the ages of men? The Lady Prioress, in some ages, predominates; and in some the Wife of Bath, in whose character Chaucer has been equally minute and exact. . . ." ${ }^{8}$ Karl Kiralis, elaborating on Foster Damon's initial insight, analyzes the Prioress and the Wife of Bath, their jewelry, costume and paraphernalia to demonstrate the identification of the two women as Tirzah the Prude and Rahab the Whore, respectively. ${ }^{59}$ The Wife's 'morning draught of comfort' emphasized in all three of Blake's descriptions of his design $^{60}$ is interpreted as Rahab's, that is the Whore of Babylon's, cup of fornications. ${ }^{61}$ Although Kiralis does not cite it, Blake's contemporary illustration of Revelation 17:1-4, featuring the Great Whore posed on the seven-headed Beast, holding her cup and wearing a large heart-shaped pendant gives good evidence for the identification in Blake's mind of the Wife of Bath with the Whore of Babylon. ${ }^{62}$ The Wife's sensual, manipulative nature, as well as her frankly expressed desire to have "al the soveraynetee," 63 are indeed appropriate to Blake's characterization of Rahab as the Female Will. To demonstrate the Prioress's identification with Tirzah, Kiralis points to her posed position, uncovered forehead and teasingly-revealed upper arms, breasts and shoulders. ${ }^{64} \mathrm{He}$ further interprets the reticulated trappings of her horse as the Veil of Vala, ${ }^{65}$ and the small white dogs beside her as her inner impulses. They "are the picture of prim dignity," he writes, "the image the Lady Prioress tries to reflect, though the jumping one suggests some kind of anxiety, which the female Prioress must have under her calm exterior."66 Although he did not, Kiralis might have pointed out a persuasive link between the Prioress and the idea of prudery, for Blake's tenth and eleventh illustrations to Thomas Gray's "A Long Story" feature women wearing various old-fashioned head-dresses, among them the pedimental form worn by the Prioress, and accompanying the lines "The ghostly prudes with haggard face/ Already had condemn'd the sinner." ${ }^{67}$ This peaked head covering is Blake's own detail, but many other features of clothing come directly from Chaucer's text. One is always aware, as Warren Stevenson points out, of "the subtlety of Blake's technique, and . . . his skillful efforts to reconcile reasonable fidelity to Chaucer's text with fidelity to his own vision. . . ." 68 Where fidelity is achieved, however, his suspected divergence from the spirit of the original must be explored with caution.

For his own part, Blake discusses the Prioress at some length, giving particular emphasis to her youth and her attendant greyhounds. "Th "Th Lady," he states further, "is described also as of the first rank, rich and honoured. She has certain peculiarities and little delicate affectations, not unbecoming in her, being accompanied with what is truly grand and really polite; her person and face Chaucer has described with minuteness; it is very elegant, and was the beauty of our ancestors, till after Elizabeth's time, when voluptuousness and folly began to be accounted beautiful."70 Blake's comments and his visual representation of the Prioress take on new significance when viewed in terms of the monumental effigy of Elizabeth of York, whose granddaughter, Elizabeth I, Blake associates with the turningpoint in tastes concerning feminine beauty. Torrigiani's bronze effigy portrays the former as young and beautiful, her forehead and neck uncovered 
and her long hair hanging over her shoulders under her pedimental headdress. Her arms are cased in tight sleeves to the wrist, and a horizontal line under her breast suggests a difference of cut or material in the upper part of her robe. All these features are reflected in Blake's portrait of the Prioress. The metal grille through which the tomb must be viewed adds further details. It is, in W.R. Lethaby's words, "an extraordinarily beautiful work, . . . conceived with great frankness as a little building of brass, all of open-work lattices, traceries, and brattishings . . . the details sharp and vivid; and the inscriptions, badges of greyhounds and red dragons, and images, are triumphs of skill." ${ }^{71}$ Blake in his comments on the Canterbury Pilgrims is at great pains to ascribe the "greyhounds" in the design - which in Chaucer's text are merely "smale houndes" - to the Prioress. The Monk, who rides close by, Chaucer describes as given to hunting with "Grehoundes" 72 and Blake, it would appear, took no chances that the "fair prelaat" might be mistaken for their owner. The animals on the screen confronting the dragons are very like the Prioress's dogs, and represent the Beaufort greyhound, badge of the King's mother's family. ${ }^{73}$ Anyone looking at these creatures might conclude, though incorrectly, that since the dragon obviously represents the House of Tudor, the greyhound must logically stand for the House of York, and thus be the badge of the Queen. But understood this way or not, Elizabeth of York's effigy cannot be viewed without numerous and conspicuous decorative greyhounds lying directly in one's line of vision. The additional presence of roses, on the tomb, on the grille and carved throughout the Chapel - appropriate to Tudor, Lancaster and York - is a happy coincidence, for the Prioress's name, Eglantine, is also that of the sweet briar rose. A further motif, the Beaufort portcullis, prominent on the grille, the tomb, the Chapel gates and indeed throughout the decorative carving, bears striking resemblance, despite its different orientation, to the trappings on the Prioress's horse. That Blake had this badge of the Beauforts in mind while working on the Canterbury Pilgrims is clear from his contemporary illustration to Paradise Lost, Satan Comes to the Gates of Hell, ${ }^{74}$ which features both the arrow-footed portcullis and the accompanying chain motif so conspicuous on the perforated panels of Henry VII's Chapel gates. Even the crown in this version of the portcullis badge suggests the Prioress's "crowned A" in Chaucer's text. The Nun by her side has a wimple, in contrast to the Prioress's bare neck, like that shown on Lady Margaret Beaufort's effigy which, similar in style and materials, and sharing the decorative motifs of the portcullis and the rose, lies in the south aisle of Henry VII's Chapel. The Nun's head-dress is less peaked than Lady Margaret's but is still roughly pedimental in form; a head covering beneath it, while present, does not hide her hair as Lady Margaret's does. Elizabeth's youthfulness and Lady Margaret's elderly appearance are also reflected in Blake's characterization. These two tombs, in fact, exemplify a turning-point in the Abbey's history. Although expressive of the purest Renaissance tradition, ${ }^{75}$ they represent the last of the mediaeval royal monuments and the last, indeed, before the great upheaval in the English Church. Writing of Lady Margaret who outlived both her son and daughter-in-law, Dean Stanley observes: "Strikingly are the old and the new combined as, round the monument of that last mediaeval 
Princess, we trace the letters of the inscription written by [Erasmus] the first and most universal of the Reformers. We feel, as we stand by her tomb, that we are approaching the great catastrophe." 76

By the time Elizabeth Tudor came to the throne, a drastic change had taken place. Blake's reference to "the beauty of our ancestors till after Elizabeth's time when voluptuousness and folly began to be accounted beautiful" could well apply to tastes in monuments for, in this reign, the Abbey took on the new function of 'Temple of Fame', ${ }^{77}$ with memorials to great ladies of the court predominating. These monuments in Lawrence Tanner's words were "monumental in every sense of the word, and . . . were so designed that they had perforce to be fixed for support against the walls of the Church. As their height would have obscured the windows many of them occupy the site of the former altars, which were usually placed against windowless walls in the side Chapels." ${ }^{78}$ The first tomb to displace an altar was that of Frances Grey, Duchess of Suffolk, who died in the year of Elizabeth's accession. ${ }^{79}$ Elizabethan effigies display the form-distorting dress that was the fashion: farthingales, ruffs and showy sculptured jewelry. On the evidence of Abbey monuments, "voluptuousness and folly" were accounted beautiful from the beginning of Elizabeth's reign, and not merely after her death.

That the Wife of Bath's costume has an Elizabethan air can be seen at a glance, but comparing the Wife's overall appearance with that of Elizabeth Tudor's effigy produces surprising similarities. Physically they are both of advanced years, with aquiline noses, thick necks and faces wide at the cheekbones. Although Chaucer describes her as well-wimpled, ${ }^{80}$ Blake's Wife reveals her neck and bosom as does Elizabeth, and both wear heavy beads and pendants matched with dangling ear-rings. Each wears a point lace frill to her chemise turned back, although the Wife lacks Elizabeth's broad plaited ruff beneath it. The Queen, like the Wife, wears a close coif but lacks the Wife's head-dress, specified by Chaucer, which Kiralis describes as "resembling the Pope's tiara with an ironic suggestion of a halo." ${ }^{81}$ These papal associations would of course be appropriate to Elizabeth as head of the English Church. As Queen she calls to mind the Elf Queen in the Wife's Tale. Ever courted, ever virgin, she epitomizes both Rahab's role of Virgin Whore and her characterization as the Female Will. In illustration 11 to Gray's "The Bard" Blake depicted a youthful Elizabeth wearing a frill very like the Wife of Bath's, which Geoffrey Keynes describes as "conspicuously spiked, shewing again Blake's hatred of the Monarchy." ${ }^{82}$ It is worth noting that in his Vision of The Last Judgment, roughly contemporaneous with the Canterbury Pilgrims, Blake wrote: "In Eternity Woman is the Emanation of Man; she has No Will of her own. There is no such thing in Eternity as a Female Will, \& Queens [of England $d e l$.]" ${ }^{\prime 83}$ Northrop Frye has pointed out the poet's affinity to the Elizabethans, but there is no reason to suppose Blake admired the Elizabethan Establishment. ${ }^{84}$ Among his annotations to Bacon, his comment that "It was a Common opinion in the Court of Queen Elizabeth that Knavery Is Wisdom," ${ }^{85}$ suggests far otherwise. Significantly, the Merchant, positioned confidentially at the Wife's left ear, bears a suggestive resemblance to portraits of the Lord Chancellor. A further hint of the connection between 
these two and its destructive nature is the apparently gothic steeple above their heads. It is, in fact, a faithful rendition of the belfry of St. Dunstan's in the East, a gothic imitation by Sir Christopher Wren. ${ }^{86}$ Blake accused Bacon of being a Contemplative Atheist, making "Pretence to Religion to destroy Religion." 87 Wren's imitation, obvious from "the flatness, shallowness and littleness of its mouldings", ${ }^{88}$ he would no doubt have considered, as he did Reynolds' Discourses, "A Pretence of Art, To destroy Art." ${ }^{\text {"89 }}$ Church Establishment - State Religion - traceable to Elizabeth Blake refers to as "The Abomination that maketh desolate,"

... thus Rahab is reveal'd,

Mystery, Babylon the Great, the Abomination of Desolation,

Religion hid in War, a Dragon red \& hidden Harlot. ${ }^{91}$

To return to the Canterbury Pilgrims: if the greyhound is appropriate to the Prioress, the dragon facing it on Henry VII's grille is equally appropriate to the Wife in her association with Rahab as well as to Elizabeth Tudor, whose dynasty it represents. In fact Blake's reference, elsewhere in Jerusalem, to "Babylon the Great" as "The Druid Dragon"92 makes such an association difficult to refute. Elizabeth of York and Elizabeth Tudor can be seen to confront each other much as the greyhound and the dragon do: the one whose marriage ended the Wars of the Roses and whose children established the Tudor dynasty; the other whose refusal to marry, and thus relinquish power over Church and State, brought the dynasty to an end. The one belonging to the Old Dispensation of "true enthusiastic superstition," ${ }^{93}$ as Blake calls mediaeval Catholicism; the other initiating a state religion and appropriating the churches for the glorification of courtiers and politicians rather than the glory of God. A reversal of civil status, associating the mother of the Tudors with the celibate Prioress and the much-married Wife with the Virgin Queen, is fully consistent with Blake's theory of history as he expounds it in $A$ Descriptive Catalogue, his apologia for the Canterbury Pilgrims:

The characters of Chaucer's Pilgrims are the characters which compose all ages and nations: as one age falls, another rises, different to mortal sight, but to immortals only the same; for we see the same characters repeated again and again. . .

. . . some of the names or titles are altered by time, but the characters themselves for ever remain unaltered, and consequently they are the physiognomies or lineaments of universal human life. . . ${ }^{94}$

In his apprentice years Blake's studies, as Malkin writes, took him "over all the old monuments in Westminster Abbey . . . ,"95 and must have early impressed upon him the co-occurrence of varying styles of dress and beauty there, embodying simultaneously the linear and the cumulative view of history and taste. Given his interpretation, thirty years later, of Chaucer's pilgrimage as that of every age involving universal human types, Blake's use of costumes drawn from various times is more suited to the spirit of this view than dress uniformly representative of Chaucer's day could be. One wonders if the germ of this visionary concept of history may first have been implanted in the Abbey where, as Malkin affirms, "he drew [its monuments] in every 
point he could catch, ... The heads he considered as portraits; and all the ornaments . . as miracles of art." 96 What better source than these could Blake have chosen when illustrating Chaucer in his later years to exemplify the "lineaments of universal human life"?

M.E. Reisner

Laval University

\section{Notes}

'A Father's Memoirs of His Child, reprinted in G.E. Bentley, Jr., Blake Records (Oxford: Clarendon Press, 1969), p. 422.

${ }^{2}$ Mona Wilson, The Life of William Blake, new ed., Geoffrey Keynes (London: Oxford Univ. Press, 1971), p. 233.

${ }^{3}$ Malkin, op, cit., p. 422.

${ }^{4}$ All Blake quotations are from The Complete Writings of William Blake, ed., Geoffrey Keynes (London: Oxford Univ. Press, 1966) and are identified as K. K 461, 604, 610 and 778; also designs to Jerusalem plates 46,57 and 84 .

s Paul Miner, "The Apprentice of Great Queen Street," BNYPL, 67, (Jan.-Dec. 1963), 639-40. Geoffrey Keynes, Blake Studies, (Oxford: Clarendon Press, 1971), pp. 16-18.

${ }^{6}$ Anthony Blunt, The Art of William Blake (London: Oxford Univ. Press, 1959), pp. 3-4 and p. 3 n. 4; Miner, pp. 641-42; Keynes, Blake Studies, pp. 20-24.

7 Especially in Jean H. Hagstrum, William Blake: Poet and Painter (Chicago: The Univ. of Chicago Press, 1964), p. 77 et passim.

${ }^{8}$ Blunt, plates $42 \mathrm{a}-\mathrm{d}$.

9 William Gaunt, Arrows of Desire (London: The Museum Press Limited, 1956), p. 32.

${ }^{10}$ Kathleen Raine, William Blake (New York, Washington: Praeger Publishers, 1970), p. 19.

"Part of the information about Blake sent by John Linnell to Alexander Gilchrist, cited by Bentley, p. 318 n. 2.

${ }_{12}$ The two most recent studies of the impact of Gothic art on Blake pay only the slightest attention to his contact with it in the Abbey: cf., Roger R. Easson, "Blake and the Gothic," Blake in His Time, ed. Robert N. Essick and Donald Pearce (Bloomington and London: Indiana Univ. Press, 1978), pp. 145-54; and Edward J. Rose, "The 'Gothicized Imagination' of 'Michelangelo Blake'," ibid., pp. 155-69.

${ }^{13}$ Life of William Blake, A New and Enlarged Edition (New York: Phaeton Press, 1969), p. 18.

${ }^{14}$ Bentley, p. 422.

is Jocelyn Perkins, Westminster Abbey: Its Worship and Ornaments (London: Humphrey Milford, Oxford Univ. Press, 1938), III, p. 131. Services in the summer were held at 6, 10 and 3 .

${ }^{16}$ Perkins, III, p. 149. See also Lawrence E. Tanner, Westminster School (London: Country Life Ltd, 1934), p. 68.

17 Perkins, III, p. 143.

${ }_{18}$ Perkins, III, p. 154.

19 January 30th and May 29th: Perkins, III, p. 131. A third official service was held on November 5th: Perkins, III, p. 144.

${ }^{20}$ Perkins, III, pp. 145-46.

${ }^{21}$ Adam Fox, The Pictorial History of Westminster Abbey (London: Pitkin Ltd, 1962), p. 18.

${ }^{22}$ Perkins, III, pp. 141-42.

${ }^{23}$ Spectator, No. 329: "Sir Roger Visits Westminster Abbey".

${ }^{24}$ The Citizen of the World, Letters XII and XIII.

${ }^{25}$ Cf. K 592-93; 596.

${ }^{26}$ Blunt, pp. 2-3; Hagstrum, p. 24; Raine, p. 12; and Morton D. Paley, “'Wonderful Originals' - Blake and Ancient Sculpture," Blake in His Time, p. 171.

${ }^{27}$ W.R. Lethaby, Westminster Abbey Re-examined (London: Duckworth \& Co., 1925), p. 217.

${ }^{28}$ Especially Eleanor de Bohun's fourteenth-century brass: cf. George Gilbert Scott, Gleanings from Westminster Abbey (London: John Henry and James Parker, 1863), pp. 189-90, and 
Francis Bond, Westminster Abbey (London: Henry Froude, Oxford Univ. Press, 1909), p. 180.

${ }^{29}$ Lethaby, p. 217. Cf. also p. 220.

30 "The Sedilia", in Scott, Gleanings, p. 119.

${ }^{31}$ Lawrence E. Tanner, Unknown Westminster Abbey (Harmondsworth, Middlesex: Penguin Books, 1948), p. 15.

32 W.R. Lethaby, Westminster Abbey and the Kings' Craftsmen (London: Duckworth \& Co., 1906), p. 230.

33 Bond, pp. 132-34, and Westminster Abbey, Vol. I of Royal Commission on Historical Monuments (England) (London: His Majesty's Stationers' Office, 1924), p. 20.

34 Westminster Abbey and the Kings' Craftsmen, p. 239 n.

35 Bond, p. 205.

36 Westminster Abbey Re-examined, p. 203.

${ }^{37}$ The Drawings and Engravings of William Blake, ed. Geoffrey Holme (London: The Studio Limited, 1922), p. 28.

38 Westminster Abbey and the Kings' Craftsmen, p. 240.

39 Elspeth M. Veale, Studies in London History, ed. A.E.J. Hollaender and William Kellaway (London: Hodder \& Stoughton, 1969), p. 147.

40 Bentley, p. 15.

41 Roy Strong, And when did you last see your father? (London: Thames and Hudson, 1978), p. 13.

42 Blunt, p. 7.

43 Strong, p. 24.

${ }^{44}$ The Regal and Ecclesiastical Antiquities of England (1773), Complete View of the Dress and Habits of the People of England (1796-99), and The Sports and Pastimes of the People of England (1801).

45 Treatise on Ancient Armour and Weapons (1786).

${ }^{46}$ Richard Gough's Sepulchral Monuments of Great Britain (1786-99) and Charles Alfred Stothard's The Monumental Effigies of Great Britain (1811-33).

47 K 567.

48 Strong, p. 58.

49 W. Burges's "The Brasses", in Scott, Gleanings, p. 189.

50 Blunt, plate $2 \mathrm{a}$.

st Keynes, Blake Studies, p. 23.

s2 W. Burges's "The Tombs", in Scott, Gleanings, p. 150.

53 "Ancient Arms in Westminster Abbey", in Scott, Gleanings, p. 298.

54 K 570 .

55 S. Foster Damon, A Blake Dictionary (Providence, R.I.: Brown Univ. Press, 1963), p. 79, comments on rank; Walter Clyde Curry, Chaucer and the Mediaeval Sciences, rev. ed. (London: Allen and Unwin, 1960), p. 65, states that there is no evidence that the pilgrims of high rank have had "any close association whatever with the Pardoner."

56 Arthur Penrhyn Stanley, Historical Memorials of Westminster Abbey (London: John Murray, 1868), p. 134.

57 James Winny, The General Prologue to the Canterbury Tales (Cambridge: Cambridge Univ. Press, 1965), p. 22.

$58 \mathrm{~K} 572$.

59 Damon, p. 79. Karl Kiralis, "William Blake as an Intellectual and Spiritual Guide to Chaucer's Canterbury Pilgrims," Blake Studies, 1 (Spring 1969), 148-62 et passim. Warren Stevenson, "Interpreting Blake's Canterbury Pilgrims," Colby Library Quarterly, 13, (June 1977), 120.25 and Orphia Jane Allen, "Blake's Archetypal Criticism: The Canterbury Pilgrims," Genre, 11, (1978), 181-83 adhere to this interpretation.

60 K 567, 588, 590 .

${ }^{61}$ Revelation 17:4.

${ }^{62}$ Stevenson, pp. 119, 124 cites it.

${ }^{63}$ The Works of Geoffrey Chaucer, ed. F.N. Robinson, 2nd ed. (Boston: Houghton Mifflin Company, 1957), WBP, 1.818.

${ }^{64}$ Kiralis, p. 148.

65 Kiralis, pp. 154-55. 
66 Kiralis, p. 161.

67 William Blake's Water-Colour Designs for the Poems of Thomas Gray, intro. Geoffrey Keynes (London: Trianon Press for the William Blake Trust, 1971), designs 32 and 33.

68 Stevenson, p. 119.

69 K 566, 588, 589 .

$70 \mathrm{~K} 568$.

7 Westminster Abbey and the King's Craftsmen, p. 232.

72 Gen Prol, 1. 190.

${ }^{73}$ John Woodward and George Burnett, Woodward's A Treatise on Heraldry British and Foreign (Rutland, Vt.: Charles E. Tuttle Co., 1969), p. 595; use as supporters, p. 662.

${ }^{74}$ Catalogue of William Blake's Drawings and Paintings in the Huntington Library, enlarged and rev. R.R. Wark (San Marino, Ca.: The Huntington Library, 1969), plate II, dated (1807).

75 Westminster Abbey Re-examined, p. 203: "The tomb portraits of Henry VII and his Queen, with a third figure of the King's mother near by . . . are really great works of the Italian Renaissance. . . . They follow the tradition of Donatello and, if they were in Italy, they would be noted among the most wonderful things that could be seen on tour."

76 Stanley, p. 166.

77 Stanley, p. 200.

78 Lawrence E. Tanner, The History and Treasures of Westminster Abbey (London: Pitkin Pictorials Ltd, 1953), p. 66.

79 Stanley, p. 198.

80 Gen Prol, 1. 470.

81 Kiralis, p. 148.

${ }_{82}$ Water-Colour Designs for the Poems of Thomas Gray, p. 59.

$83 \mathrm{~K} 613$.

${ }^{84}$ Northrop Frye, Fearful Symmetry (Boston: Beacon Press, 1962), p. 9. S. Foster Damon, William Blake: His Philosophy and Symbols (Gloucester, Mass.: Peter Smith, 1958), p. 172, suggests that Blake did, in fact, admire it.

$85 \mathrm{~K} 397$.

${ }^{86}$ See engravings of "Wren's Steeples", in The Pictorial Handbook of London . . . (London: Henry G. Bohn, [1861]), and pp. 196-197 on St. Dunstan's in particular.

${ }^{87} \mathrm{~K} \mathrm{403,398.}$

88 The Pictorial Handbook of London, p. 196.

$89 \mathrm{~K} 452$.

$90 \mathrm{~K} 393$.

$91 \mathrm{~K} 716$ : plate 75, 11. 18-20.

92 K 741: plate 93, 1. 25.

$93 \mathrm{~K} 575$.

$94 \mathrm{~K} 567$.

95 Bentley, p. 423.

96 Bentley, pp. 422-23. 